\title{
Shadow Banking, Interest Rate Marketization and Bank Risk-Taking: An Empirical Study of the 40 Commercial Banks in China
}

\author{
Jing Luo \\ Department of Finance, Jinan University, Guangzhou, China \\ Email: 286936267@qq.com
}

How to cite this paper: Luo, J. (2017). Shadow Banking, Interest Rate Marketization and Bank Risk-Taking: An Empirical Study of the 40 Commercial Banks in China. Journal of Financial Risk Management, 6, 27-36.

https://doi.org/10.4236/jfrm.2017.61003

Received: February 7, 2017

Accepted: February 26, 2017

Published: March 1, 2017

Copyright $\odot 2017$ by author and Scientific Research Publishing Inc. This work is licensed under the Creative Commons Attribution International License (CC BY 4.0).

http://creativecommons.org/licenses/by/4.0/

\begin{abstract}
Based on the panel data of 40 Commercial Banks in China during 2006-2014, this paper makes an empirical study on the relationship between shadow banking, interest rate marketization and bank risk-taking by using the system GMM model. The study found that the development of the shadow banking and the interest rate marketization is conducive to the diversification of banks' business, thereby reducing the risk of banks. The study also found that "too big to fail" and periodic are the characteristics of commercial bank risk.
\end{abstract}

\section{Keywords}

Shadow Banking, Interest Rate Marketization, Risk-Taking, Industrial Diversification

\section{Introduction}

Interest rate marketization has always been the core of financial liberalization, is also necessary for China's financial reform. In June 1996, the central bank deregulated the interest rates of inter-bank lending market, by letting trading partners to determine their own interest rate according to the market. And from then on, the market-oriented reforms of interest rates began in China. From 2004 to July 2013, China has gradually deregulated the loan interest rate, cancelled the lower limit of the lending rate, and allowed deposit interest rate to float up to 1.1 times from the benchmark interest rate. Since the acceleration of the market-oriented interest rate reform and the regulation on traditional credit business, the Chinese commercial banks start their own shadow banking business.

Unlike the most developed countries, the shadow banking has been closely linked to traditional commercial in China since it arose. With the deepening 
contradiction between the commercial banks' lending demand and the supervision of regulator, banks with higher risk appetite started to make loans to economic entities through shadow banking business.

Shadow banking business developed rapidly in China since 2010. According to the Chinese shadow banking monitoring report by Moody's, Chinese shadow banking assets grew by $30 \%$ in 2015 , the total asset had increased to more than 53 trillion Yuan by the end of 2015. According to the annual reports of some banks and news, the ultimate demanders of shadow banking capital are mainly the Local Government Funding Vehicle, infrastructure projects and real estate developers who lack of financing capacity. Facing to the rapid development of the shadow banking business, Chinese regulators have issued a series of supervision, for example, No. 127 [2014] Document of the China Banking Regulatory Commission stipulates that the financial assets only with high liquidity can be the underlying assets of Redemptory Monetary Capital for Sale, and No. 82 [2016] Document of the China Banking Regulatory Commission tightens the regulation of the transfer of non-standard credit assets to off-balance sheet.

\section{Literature Review and Hypotheses}

\subsection{Literature Review}

Many scholars have made a research on the relationship between interest rate liberalization and bank risk. Demirgüç-Kunt \& Detragiache (1998) believes that there is a significant positive correlation between the interest rate liberalization and commercial bank crisis. But if the institutional environment like legal constraints and the efficiency of government regulation supports interest rate marketization reform, the possibility of bank crisis caused by interest rate marketization reform will significantly reduce. Angkinand et al. (2010) found the relationship between the degree of financial liberalization and bank risk pictures a reverse U-shape, and it depends on the strength of capital regulation to a large extent. Borio \& Zhu (2008) pointed out the low interest rate will reduce the risk tolerance of banks, which is conducive to enhancing the level of risk-taking. According to Delis \& Kouretas (2010), whose paper was based on the data of the bank in euro area of the year of 2001-2008, low interest rate level will increase the level of bank risk-taking. With the increase of the capital ratio, the influence of interest rate on bank risk assets will reduce, besides, it will improve the impact on the asset of off-balance sheet. As for China, Porter et al. (2015) stated that interest rate liberalization reform in China needs to improve the level of deposit interest rate, which is conducive to improve the effectiveness of investment. And it will make more and more funds flow to SMEs and the real estate industry, but it may also bring risk some large commercial banks. Zhang et al. (2012) found that the cancellation of the interest rate cap could lead to a periodic operating risk. Zuo et al. (2014) found that the deposit interest rate marketization may reduce capital ratios, but not increase the banks' risk through empirical research. Unlike Zuo's research result, Peng et al. (2014) believe the deposit interest rate marketization will increase the risk of bankruptcy and non-performing loans, 
and is not conducive to raising capitalization from the data of urban commercial banks.

Shadow banking system is also the focus of academic research in recent years. Western researchers believe that the shadow banking is a kind of financial intermediation of transforming term, credit and liquidity, which get much liquidity with little capital by amplifying leverage, and it will result in a huge bubble of capital market crisis (Gorton et al., 2010; Pozsar et al., 2013). Gorton \& Souleles (2007), Minton et al. (2004) believe that shadow banking can reduce bank risk. Because the bank not only transfers part of bank credit risk to external investors, but also makes the risk shared by the whole capital market through asset securitization. It also helps banks improve their liquidity. Some other scholars pointed out when banks spread risk through asset securitization and other off-balance sheet business, it reduces the bank's capital adequacy requirements on the one hand, and increases the system risk on the other hand (Iori et al., 2006; Gennaioli et al., 2010). Most of the scholars in China studied in the shadow banking business through the shadow banking crisis transmission mechanism and the effect on the financial stability (He et al., 2009; Mao \& Wan, 2012). Ding (2015) found that the development of the shadow banking can boost the profitability of commercial banks in next year. Zhu et al. (2016) found that the larger the size of shadow banking business, the greater the operational risk facing by the commercial banks, through the data of Chinese commercial banks in 2006-2012.

Drew on the research above, this paper researches on the risk-taking of commercial banks influenced by the development of shadow banking business and interest rate liberalization from the perspective of the interest spreads narrowing and outflow of capital in shadow banking.

\subsection{Theoretical Analysis and Hypotheses}

With the gradual reduction of deposit rate, banks' profitability which relies on traditional credit business weakened. In order to get rid of the single source of income constraints, banks actively develop intermediary business. Therefore, the source of income has become increasingly diversified, and it will help alleviate the fluctuation of income. The release of the loan interest rate lower limit promotes the careful pricing of the credit assets and the effective competition of the industry, weakens the problem of adverse selection and moral hazard, and is helpful to alleviate the credit risk of the bank. In a short time, interest rate marketization may affect the bank's income, but it will prompt banks to innovation, and ultimately rich banks' business structure, reduce the risk of banks. Therefore, this paper proposes the hypothesis:

$\mathrm{H1}$. There is a negative correlation between bank risk and interest rate marketization, that is, the higher the level of interest rate marketization, the lower the bank risk.

The development of shadow-banking business increases the loan supply, reduces the loan interest rate, enriches the bank's business structure, and improves the profitability of banks in the long run. And the improving of the banks' prof- 
itability is conducive to enhance their ability to lower risk. This paper proposes the hypothesis:

H2. The development of shadow-banking business is conducive to reducing the bank's risk-taking level, that is, the larger the size of the shadow banking business, the lower the level of bank risk-taking.

\section{Sample and Variables}

\subsection{Sample}

The sample of this paper consists of 40 main commercial banks in China from 2006 to 2014 and include the data from the year of 2005 to 2015. It includes 5 state-owned commercial banks, 11 national joint commercial banks and 24 urban commercial banks. In the model, we use 2 dummy variables to control bank types.

The banks' data come from Wind database and banks' annual reports. There are 16 banks listed on the Shanghai Stock Exchange and Shenzhen Stock Exchange, the data of these banks can download from Wind database which contains data of stocks, fund, bonds, derivatives, listed companies, macroeconomy, industry and high-frequency trading. Some other banks cannot find data from Wind database, therefore I collected their data from their annual reports manually. The macro data were also collected from Wind database. Due to the lack of some data, this paper contains 295 valid samples by taking out some samples with missing data.

\subsection{Variables}

\subsubsection{Dependent Variables}

According to the research on the bank risk-taking, the common indicators include Z-score, non-performing loan ratio, earnings volatility, capital return and expected default probability. This paper will choose the Z-score as the measurement of risk-taking, and use the data processing method of Zhang \& Wang (2012). The Z-score is defined as follow:

$$
\mathrm{ZROA}_{i, t}=\left(R O A_{i, t}+C A R_{i, t}\right) / \sigma_{i, t}(R O A)
$$

where $R O A$ is the average return on total asset for three years, CAR means the average capital adequacy ratio for three years, and $\sigma$ indicates that the standard deviation of the return on total asset for 3 years in a row (from $t-1$ to $t+$ 1). As a measure of bankruptcy risk, the greater the Z-score is, the smaller the bankruptcy risk is.

\subsubsection{Explanatory Variables}

\section{1) Shadow banking business}

Following the research of Zhu et al. (2016), this paper will use the ratio of Redemptory Monetary Capital for Sale (the size of Redemptory Monetary Capital for Sale divided by the total asset of commercial bank) as the indicator of the size of commercial banks' engagement in shadow banking. 


\section{2) Interest rate liberalization}

Zuo et al. (2014) and other scholars suggested that the constriction of NIM (net interest margin) can effectively reflect the interest rate marketization level. Therefore, this paper measures the level of interest rate liberalization by NIM.

$$
N I M=L I R-D I R
$$

where $L I R$ is the actual lending interest rate (bank's interest income divided by total earning assets), $D I R$ is the actual deposit interest rate (bank's interest expense divided by the sum of total deposits and short-term loans).

\subsubsection{Control Variables}

As for other factor that influence bank's bankruptcy, this paper mainly considers two aspects including bank management and macroeconomic environment. In respect of bank management, this paper considers four variables: size, profitability, liquidity and operational efficiency. The size of bank is represented by the total assets. The profitability is represented by the return on total assets. The liquidity is represented by the ratio of loan to deposit. And the operating efficiency is represented by the ratio of cost to income. In respect of macroeconomic environment, this paper uses GDP annual growth rate represents the economic growth. The description of all variables is provided in Table 1.

\subsubsection{Descriptive Statistics}

Table 2 presents summary statistics for variables. The mean of shadow banking is 7.371, which indicates that the average ratio of Redemptory Monetary Capital for Sale is $7.371 \%$. The maximum value is 31.534 , and the minimum value is 0 , indicating that the size that commercial bank engaged in Redemptory Monetary Capital for Sale varies in different samples. In this paper, the values of LnNIM range between 0.434 and 2.258, which the sample with largest value is Linshang Bank in 2008 and the sample with smallest value is Hengfeng Bank in 2009. The samples which are state-owned commercial banks account for $14.2 \%$, while urban commercial banks account for $54.9 \%$ of samples. Others are national joint commercial banks.

Table 1. List of variables.

\begin{tabular}{|c|c|}
\hline Variables & Description \\
\hline $\operatorname{LnZ}$ & Natural logarithm of Z-score \\
\hline Shadow & The ratio of Redemptory Monetary Capital for Sale \\
\hline LnNIM & Natural logarithm of net interest margin \\
\hline LnSize & Natural logarithm of size \\
\hline LnROA & Natural logarithm of return on total assets \\
\hline LnDTL & Natural logarithmof the ratio of deposit-to-loan \\
\hline LnCIR & Natural logarithm of the ratio of cost to income \\
\hline LnGDP & Natural logarithm of GDP \\
\hline Dum1 & Dum $1=1$, if it is a state-owned commercial bank;otherwise, Dum $1=0$ \\
\hline Dum2 & Dum2 $=1$, if it is an urban commercial bank;otherwise, Dum $1=0$ \\
\hline
\end{tabular}


Table 2. Descriptive statistics of variables.

\begin{tabular}{ccccc}
\hline Variables & Mean & Std & Min & Max \\
\hline LnZ & 4.817 & 0.980 & 2.226 & 8.671 \\
Shadow & 7.371 & 6.135 & 0 & 31.534 \\
LnNIM & 1.029 & 0.253 & 0.434 & 2.258 \\
LnSize & 6.056 & 1.875 & 2.658 & 9.934 \\
LnROA & 0.069 & 0.386 & -2.851 & 0.785 \\
LnDTL & 4.185 & 0.117 & 3.766 & 4.428 \\
LnCIR & 3.515 & 0.174 & 3.010 & 3.997 \\
LnGDP & 2.211 & 0.187 & 1.988 & 2.653 \\
Dum1 & 0.142 & 0.350 & 0 & 1 \\
Dum2 & 0.549 & 0.498 & 0 & 1 \\
\hline
\end{tabular}

\section{Empirical Results and Analysis}

\subsection{Model Design}

Based on the research above, this paper takes the shadow banking business development and interest rate marketization as the main independent variables to construct the model.

$$
\begin{aligned}
& \operatorname{LnZ}_{i, t}=\alpha_{0}+\alpha_{1} \operatorname{LnZ}_{i, t-1}+\alpha_{2} \text { Shadow }_{i, t}+\alpha_{3} \text { LnNIM }_{i, t}+\alpha_{4} \text { LnSize }_{i, t-1} \\
& +\alpha_{5} \operatorname{LnROA}_{i, t-1}+\alpha_{6} \operatorname{LnDTL}_{i, t-1}+\alpha_{7} \operatorname{LnCIR}_{i, t-1}+\alpha_{8} \operatorname{LnGDP}_{t} \\
& +\alpha_{9} D U M 1+\alpha_{10} D U M 2+\varepsilon_{i, t}
\end{aligned}
$$

In the model (1), " 1 " represents the bank entity, " $t$ " means the year. Among them, "LnZ" means the bank's risk, and is the explanatory variable of the model. we considered the endogeneity of explanatory variable in our regression models and adopted GMM method to resolve the problem of endogeneity. The interaction item was added to the model (2) to further measure the effect that shadow-banking affect the risk-taking by influence the interest rate liberalization.

$$
\begin{aligned}
& \operatorname{LnZ}_{i, t}=\alpha_{0}+\alpha_{1} \operatorname{LnZ}_{i, t-1}+\alpha_{2} \text { Shadow }_{i, t}+\alpha_{3} \text { LnNIM }_{i, t}+\alpha_{4} \text { Shadow }_{i, t} * \text { LnNIM }_{i, t} \\
& +\alpha_{5} \text { LnSize }_{i, t-1}+\alpha_{6} \text { LnROA }_{i, t-1}+\alpha_{7} \text { LnDTL }_{i, t-1}+\alpha_{8} \operatorname{LnCIR}_{i, t-1} \\
& +\alpha_{9} \operatorname{LnGDP} P_{t}+\alpha_{10} D U M 1+\alpha_{11} D U M 2+\varepsilon_{i, t}
\end{aligned}
$$

\subsection{Results}

This paper uses first differenced GMM model to test model (1) and (2), and conducts the robustness tests by using random effects model. Thus, the empirical test is divided into 4 sub models, the regression results are shown in Table 3.

From the regression results of model 1-4, the regression of each model is significant, indicating that the model is reasonable. From the regression results of model 1 and model 3, the lagged term of bankruptcy risk is highly correlated. Model 1-2, the coefficient of Shadow are significantly positive, that means shadow banking development will reduce the risk of commercial banks. This is mainly because the development of the shadow banking business increase the 
Table 3. Empirical results of shadow banking, interest rate liberalization and banks' risktaking.

\begin{tabular}{|c|c|c|c|c|}
\hline \multirow{2}{*}{$\operatorname{LnZ} Z_{t}$} & Model 1 & Model 2 & Model 3 & Model 4 \\
\hline & Difference GMM & Random Effects & Difference GMM & Random Effects \\
\hline \multirow{2}{*}{$\operatorname{Ln} Z_{t-1}$} & $0.3532^{\star * *}$ & - & $0.3635^{\star * *}$ & - \\
\hline & $(7.05)$ & - & (7.58) & - \\
\hline \multirow{2}{*}{ Shadow $_{t}$} & $0.0196^{* * *}$ & $0.0247^{\star * *}$ & 0.0359 & 0.0616 \\
\hline & $(2.27)$ & $(2.52)$ & $(1.26)$ & $(1.59)$ \\
\hline \multirow{2}{*}{$\operatorname{LnNIM}_{t}$} & $-0.7148^{\star * *}$ & $-0.7899^{* * *}$ & $-0.6122^{\star}$ & -0.5429 \\
\hline & $(-3.43)$ & $(-2.69)$ & $(-2.01)$ & $(-1.39)$ \\
\hline \multirow{2}{*}{ Shadow $_{t} *$ LnNIM $_{t}$} & - & - & -0.0185 & -0.356 \\
\hline & - & - & $(-0.70)$ & $(-0.96)$ \\
\hline \multirow{2}{*}{ LnSize $_{t-1}$} & $0.2116^{\star * *}$ & $0.4036^{* * *}$ & $0.1990^{\star * *}$ & $0.3954^{* * *}$ \\
\hline & $(4.26)$ & (4.90) & $(4.42)$ & $(5.04)$ \\
\hline \multirow{2}{*}{$\operatorname{LnROA}_{t-1}$} & 0.1976 & 0.1925 & $0.2025^{*}$ & 0.1919 \\
\hline & $(1.68)$ & $(1.24)$ & $(1.76)$ & $(1.25)$ \\
\hline \multirow{2}{*}{$\operatorname{LnDTL}_{t-1}$} & $-0.9876^{\star}$ & -0.8713 & -0.7227 & -0.8496 \\
\hline & $(-1.79)$ & $(-1.53)$ & $(-1.42)$ & $(-1.54)$ \\
\hline \multirow{2}{*}{$\operatorname{LnCIR}_{t-1}$} & 0.2703 & 0.1525 & 0.1941 & 0.1812 \\
\hline & $(0.86)$ & $(0.39)$ & $(0.63)$ & $(0.47)$ \\
\hline \multirow{2}{*}{$\operatorname{LnGDP_{t}}$} & $-1.3411^{\star \star \star *}$ & $-1.3692^{\star \star \star *}$ & $-1.2840^{\star \star \star *}$ & $-1.3813^{\star * \star}$ \\
\hline & $(-4.56)$ & $(-3.88)$ & $(-4.37)$ & $(-3.94)$ \\
\hline \multirow{2}{*}{ Dum1 } & 0.1523 & 0.0097 & 0.1958 & 0.0810 \\
\hline & $(0.93)$ & $(0.03)$ & $(1.31)$ & $(0.30)$ \\
\hline \multirow{2}{*}{ Dum2 } & $0.6954^{\star * *}$ & $1.2687^{* * *}$ & $0.6912^{\star * *}$ & $1.2711^{* * *}$ \\
\hline & $(4.54)$ & $(4.69)$ & $(4.98)$ & $(4.95)$ \\
\hline \multirow{2}{*}{ Cons } & $8.2124^{* * *}$ & $8.4809^{* * *}$ & $7.1788^{* * *}$ & $8.0819^{* * *}$ \\
\hline & $(3.50)$ & $(2.80)$ & $(3.24)$ & $(2.71)$ \\
\hline Sargan-test & 0.271 & - & 0.383 & - \\
\hline $\mathrm{AR}(1)$ & 0.000 & - & 0.000 & - \\
\hline $\operatorname{AR}(2)$ & 0.200 & - & 0.198 & - \\
\hline
\end{tabular}

Note: Figures in parenthesis are t-statistics values, and the Standard error is adjusted by heteroscedasticity. $* * *, * *$ and ${ }^{*}$ denote the significance at the level of $1 \%, 5 \%$ and $10 \%$, respectively.

supply of loans, lower loan interest rates, the traditional loan business will choose to project lending with lower risk, which reduces the rate of default and bank's bankrupt risk to a certain extent. Therefore, those projects with high risk and high yield will finance through the shadow banking business with higher interest rate, which will boost the profitability of banks, and it is consistent with some scholars' research results (Dai \& Fang, 2014; He \& Chen, 2015). 
The coefficient of LnNIM is significantly negative, indicating a narrow interest rate spread can reduce the risk of the bank. The higher the level of marketization is, the smaller the bank's risk is, which is verified in other study (Zuo et al., 2014). In the one hand, the reduction of the interest rate spread promote the competition in the bank section and lower the banks' profitability. In the other hand, the lending interest rate has been downward, which makes it prudent for banks to choose credit assets, and it is benefit for banks to control credit risk. Besides, the marketization prompted the banks to transform their loan business, focus on the intermediary business, and diversify their business structure, so as to enhance the ability to resist risk. In the model 3 and model 4, the coefficients of cross terms are negative, that means the development of shadow banking will further reduce the bank's risk and enhance its ability to resist risk through reducing the interest rate spread.

As for the control variables, the coefficient of LnSize is significantly positive, indicating that the larger the size of commercial bank is, the smaller the risk it takes, which also proves the view of "too big to fall". The coefficient of LnROA is significantly positive, which indicates the improvement of profitability can effectively alleviate the risk of bank. The coefficient of LnGDP is significantly negative. Driven by the profit, bank will expand its scale of credit assets and increase the quantity of risk asset in the boom, so as to increase the risk-taking of bank, which confirms the pro-cyclicality of the bank's risk-taking.

\section{Conclusion}

Using the data of 40 commercial banks in the year of 2005-2015and the method of GMM, this paper studied in the impact of the development of shadow-banking and interest rate liberalization on the bank's risk-taking. Through the study, we found that the development of shadow banking business increased the supply of loan, improved the profitability, and alleviated the level of bank's risk. With the development of the interest rate liberalization, banks are more cautious in traditional credit business, pay more attentions in diversified business which improve profitability and enhance the ability to resist risk. At the same time, shadow banking business further enhances the ability to resist risk by the influence of reducing the gap between loan and deposit interest rate. In addition, the size of bank, profitability, and economic development are also the significant factors affecting the risk-taking of commercial banks.

Based on the study, here's some policy suggestions. First, the traditional deposit and loan business has been unable to adapt to the current environment of the financial market. In the rapid development of shadow banking business and the environment of interest rate liberalization, commercial banks should take the initiative to adjust the development of business structure, to achieve diversification, to adapt to the financial development trend, in order to enhance their profitability to resist risks in the current environment. Secondly, in the current financial environment, the authority should further improve capability of supervision and regulate the shadow banking system to prevent commercial banks to 
avoid supervision through the shadow banking business in disguise, thereby increasing the financial risk. Thirdly, regulators should deal with financial innovation tools like shadow banking correctly. Regulators should also guide commercial banks to make good use of the shadow banking business in order to improve their profitability, resist financial risk and help the development of financial market.

\section{References}

Angkinand, A. P., Sawangngoenyuang, W., \& Wihlborg, C. (2010). Financial Liberalization and Banking Crises: A Cross-Country Analysis. International Review of Finance, 10, 263-292. https://doi.org/10.1111/j.1468-2443.2010.01114.x

Borio, C., \& Zhu, H. (2008). Capital Regulation, Risk-Taking and Monetary Policy: A Missing Link in the Transmission Mechanism? BIS Working Papers, 8, 236-251.

Dai, G. Q., \& Fang P. F. (2014). The Liberalization of Interest Rate and the Risks of Bank: A Study from the Perspective of Shadow Banking and Internet Finance. Finance Forum, 8, 13-19.

Delis, M. D., \& Kouretas, G. P. (2010). Interest Rates and Bank Risk-Taking. Mpra Paper, 35, 840-855.

Demirgüç-Kunt, A., \& Detragiache, E. (1998). Financial Liberalization and Financial Fragility. Social Science Electronic Publishing, 98, 4259-4299.

Ding, N. (2015). Analysis of the Impact of Shadow Banking Scale on the Profitability of Chinese Commercial Banks in the Process of Interest Rate Marketization. Macroeconomics, 7, 26-35.

Gennaioli, N., Shleifer, A., \& Vishny, R. (2010). Neglected Risks, Financial Innovation, and Financial Fragility. Journal of Financial Economics, 104, 452-468. https://doi.org/10.1016/j.jfineco.2011.05.005

Gorton, G. B., \& Souleles, N. S. (2007). Special Purpose Vehicles and Securitization. SSRN Electronic Journal, 5, 21. https://doi.org/10.7208/chicago/9780226092980.003.0013

Gorton, G., Metrick, A., Shleifer, A., \& Tarullo, D. K. (2010). Regulating the Shadow Banking System. Social Science Electronic Publishing, 41, 261-312.

He G. S., \& Chen F. (2015). The Empirical Analysis of Shadow Banking Business' Influence on the Commercial Banks' Profitability: Based on the Panel Data. Journal of Liaoning University: Philosophy and Social Sciences, 43, 55-61.

He, D. X., \& Zheng L. S. (2009). The Shadow Banking System and Its Impacts on Financial Stability. Economic Management Journal, 11, 20-25.

Iori, G., Jafarey, S., \& Padilla, F. G. (2006). Systemic Risk on the Interbank Market. Journal of Economic Behavior \& Organization, 61, 525-542.

https://doi.org/10.1016/j.jebo.2004.07.018

Mao, Z. S., \& Wan, Y. L. (2012). Study on China's Shadow Banking System and Threshold Effect Banking System Stability in China. Studies of International Finance, 11, 65-73.

Minton, B., Sanders, A., \& Strahan, P. E. (2004). Securitization by Banks and Finance Companies: Efficient Financial Contracting or Regulatory Arbitrage? Working Paper.

Peng, X., Li B., \& Huang Z. G. (2014). Will the Interest Rate liberalization of Deposit Increase the Risk Level of Chinese City Commercial Banks?: A GMM Study Based on Data of 24 Chinese City Commercial Banks. Finance \& Economics, 12, 1-10.

Porter, N. J., Feyzioglu, T., \& Takáts, E. (2015). Interest Rate Liberalization in China. So- 
cial Science Electronic Publishing, 58, 1-28.

Pozsar, Z., Adrian, T., Ashcraft, A. B., \& Boesky, H. (2013). Shadow Banking. Federal Reserve Bank of New York Economic Policy Review, 19, 447-457.

Zhang, J. H., \& Wang, P. (2012). Bank Risk Taking, Bank Loans, and Legal Protection. Economic Research Journal, 5, 18-30.

Zhang, Z. Y., Wu, H. Y., \& Wu, J. (2012). The Relationship between Price Competition of Commercial Banks and Risk Behavior: An Empirical Study Based on the Marketization of Loan Interest. Financial Research, 7, 1-14.

Zhu, J. G., Hu S. Y., \& Lu Z. F. (2016). The Causes and Economic Consequences of Commercial Banks' Engagement in Shadow Banking: From the Perspective of Outflow of Capital in Shadow Banking. Journal of Financial Research, 1, 66-82.

Zuo, Z., Tang X. G., \& Liu, Y. Z. (2014). Will the Deposit Interest Rate Marketization Increase Bank' Risk Level?: Based on an Angle of Narrowed Gap between Deposit and Loan Interest Rate. Finance \& Economics, 2, 20-29.

\section{Submit or recommend next manuscript to SCIRP and we will provide best} service for you:

Accepting pre-submission inquiries through Email, Facebook, LinkedIn, Twitter, etc. A wide selection of journals (inclusive of 9 subjects, more than 200 journals) Providing 24-hour high-quality service User-friendly online submission system Fair and swift peer-review system Efficient typesetting and proofreading procedure Display of the result of downloads and visits, as well as the number of cited articles Maximum dissemination of your research work

Submit your manuscript at: http://papersubmission.scirp.org/ Or contact jfrm@scirp.org 